\title{
Effect of Different Concentration of Arka Microbial Consortium on the Growth Yield and Quality of Lettuce (Lactuca sativa) $c v$. Grand rapid under Poly House in Prayagraj Agro Climatic Condition
}

\author{
N. C. Aswathi*, V. M. Prasad and Gadha Sreekumar \\ Department of Horticulture, Naini Agriculture Institute, Sam Higginbottom University of \\ Agriculture, Technology and Sciences, Prayagraj 211007 (UP), India \\ *Corresponding author
}

\begin{tabular}{l} 
K e y w o r d s \\
Arka Microbial \\
Consortium, \\
Growth, Quality, \\
Lettuce, Vitamin C \\
\hline Article Info \\
$\begin{array}{l}\text { Accepted: } \\
10 \text { November } 2020 \\
\text { Available Online: } \\
10 \text { December } 2020\end{array}$ \\
\hline
\end{tabular}

\section{Introduction}

Vegetables are integral part of Indian agriculture and nutritional security due to agiculure and nutitional security due to

\section{A B S T R A C T}

A field experiment was conducted in Research Field, Department of Horticulture, Naini Agriculture Institute, SHUATS, Prayagraj; during 2019-2020 to study the effect of different concentration of Arka microbial consortium (AMC) on growth, yield and quality of lettuce (Lactuca sativa) $c v$. Grand rapid under poly house in Prayagraj agro-climatic condition. Arka microbial consortium with different concentrations was tried. The experiment was laid out in randomized block design having 11 treatments replicated thrice. The result showed that $10 \mathrm{~g}$ Arka microbial consortium $+75 \%$ recommended dose of nitrogen, phosphorous and $100 \%$ potassium gave the minimum days to germination (4.07) followed by (4.43) $8 \mathrm{~g}$ Arka microbial consortium $+75 \%$ recommended dose of nitrogen, phosphorous and $100 \%$ potassium. Maximum days to germination (6.38) were recorded in control treatment. Maximum plant height $(13.74 \mathrm{~cm})$ was recorded in $10 \mathrm{~g}$ Arka microbial consortium $+75 \%$ recommended dose of nitrogen, phosphorous and $100 \%$ potassium and minimum $(8.78 \mathrm{~cm})$ was observed in control. Minimum days to first harvest (29.63) and last harvest (38.45), maximum number of leaves/plant (10.58) and minimum harvesting duration (5.57) was recorded in 10g Arka microbial consortium $+75 \%$ recommended dose of nitrogen, phosphorous and $100 \%$ potassium. The yield parametersaverage weight of the plant $(164.30 \mathrm{~g})$, average weight of trimmed head $(133.54 \mathrm{~g})$, yield/plot $(4.80 \mathrm{~kg})$, yield/ha (10.88t) and quality parameters- Total soluble solids (5.41 ${ }^{\circ}$ Brix $)$ and Vitamin $\mathrm{C}(8.66 \mathrm{mg} / 100 \mathrm{~g})$ and the overall acceptability in Organoleptic test was also recorded best in $10 \mathrm{~g}$ Arka microbial consortium $+75 \%$ recommended dose of nitrogen, phosphorous and $100 \%$ potassium. The maximum gross return, net return and benefit cost ratio was recorded in $10 \mathrm{~g}$ arka microbial consortium $+75 \%$ recommended dose of nitrogen, phosphorous and $100 \%$ potassium. their short duration, high yield, nutritional richness, economic viability and ability to generate on farm and off farm employment. India is the second largest producer of 
vegetables in the world. Vegetable crops have been well advocated in solving the problem of food security. They are rich source of vitamins, minerals, fibre and fair amount of protein as well as carbohydrates. In addition to local market demand vegetables have the potential for both domestic and export market. The vegetable production of our country before independence was merely about 15 million tonnes and now the total horticulture production of the country is estimated to be 306.8 million tonnes during 2017 2018.which is $2.05 \%$ higher than the previous year and $8.5 \%$ higher than the past 5 years, average production of vegetables is estimated to be about 179.7 million tonnes which is about $1.0 \%$ higher than the previous year.

Leaf vegetables, also called leafy greens, salad greens, pot herbs, vegetable greens, or simply greens, are plant leaves eaten as a vegetable, sometimes accompanied by tender petioles and shoots. Although they come from a very wide variety of plants, most shares a great deal with other leafy vegetables in nutrition and cooking method. Nearly one thousand species of plants with edible leaves are known. Leaf vegetables most often come from short-lived herbaceous plants, such as lettuce and spinach.

Lettuce (Lactuca sativa) is the most popular among salad vegetable crops. This crop, is a member of Asteraceae family, is a native to Mediterranean region. The Latin name (Lactuca)is derived from the Latin root word" lac" or "milk" .Among all the lettuce varieties, Romaine lettuce variety is famous for its nutrition values. Lettuce is mainly used in food items like wraps, sandwiches apart from using as leafy vegetable. Lettuce is one of the most important leafy vegetable crops in temperate countries. It is rich in vitamin $\mathrm{A}$ and $\mathrm{C}$ and minerals like $\mathrm{Ca}$ and iron (Aykroyd, 1963). This plant is a source of vitamins and nutrients which are highly required for human health, and because of high cellulose content, it facilitates digestion. Moreover, lettuce contains lactocin and lactucopicrin which improve sleep. Plants generally have a height and spread of 15 to 30 $\mathrm{cm}$ (6 to $12 \mathrm{in}$ ). The leaves are colorful, mainly in the green and red color spectrums, with some variegated varieties. There are also a few varieties with yellow, gold or blue-teal leaves. Lettuces have a wide range of shapes and textures, from the dense heads of the iceberg type to the notched, scalloped, frilly or ruffly leaves of leaf varieties.

Biofertilizers are microbiological fertilizer which contains selected, highly effected bacterial and fungal strains isolated from soil. Their input in soil activate appropriate microbiological processes which enable better and more uniform supply of plant nutrients like nitrogen, phosphorus and potassium, as well as some trace elements (Mrkovački et al., 2012). The binding of atmospheric nitrogen in the process of biological nitrogen fixation is the most important component in the nitrogen cycle in nature with special significance for agriculture (Mrkovački and Milić, 2001).

The overuse of mineral fertilizers, pesticides and inadequate soil management practices, significantly affect the soil quality by altering their physical, chemical, and biological properties, and hence pose a threat to sustainable crop production. At present, most farmers do not apply microbial inoculants due to various reasons such as lack of awareness, lack of a visible effect on crop growth, poor performance of applied inoculants, non availability of individual inoculants ( $\mathrm{N}$ fixers, Phosphorous solubilizers, growth promoters) at the time of application, Another major hurdle in bio-inoculant technology is poor quality microbial cultures used for inoculant formulation and the inability of these inoculant strains to compete with the native 
soil microflora. To overcome these problems, it was always felt that it would be beneficial to formulate a microbial consortium that combined multiple useful strains, in order to harness the synergistic effects amongst the microbial strains used in inoculum production, and sustained itself at threshold levels in the plant rhizosphere in order to exert the beneficial effects of inoculation. The green revolution has popularized the use of chemical fertilizers to achieve higher productivity. Excessive use of chemical fertilizers to obtain high yield resulted in several hazards to the soil, deficiency of micronutrients (Kanwar and Randhawa, 1978) and nutrient imbalance ultimately resulting in the reduction of crop yield. The chemical use is hitting the sustainability in soil and decreasing its potency. Therefore, farmers are in need of searching alternative to replace the chemical fertilizers.

Arka Microbial Consortium is a carrier based product which contains $\mathrm{N}$ fixing, $\mathrm{P} \& \mathrm{Zn}$ solubilizing and Plant Growth Promoting Microbes in a single formulation. The novelty of this technology is that farmers need not apply Nitrogen fixing, Phosphorous Solubilizing and Growth Promoting Bacterial inoculants individually. It can be conveniently, applied either through seed, soil, water and nursery media like Coco-peat. This technology considerably reduces the cost of cultivation, besides.

The synergistic effects of the formulated microbes can help in sustainable vegetable production. Advantages of the technology is early seed germination, seedlings become ready for early transplantation by 3-4 days, increased seedling vigor, reduction of $\mathrm{N}$ and $\mathrm{P}$ fertilizer requirement by $25-30 \%$, yield increases of 5-15\% in different vegetables. It can be applied either by seed treatments, coco peat enrichment methods, soil drenching, main field application etc.

\section{Materials and Methods}

An experiment entitled "Effect of Different Concentration of Arka Microbial Consortium on the Growth and Yield and quality of Lettuce (Lactuca sativa) cv. Grand rapid Under Poly house in Prayagraj Agro climatic Condition" was conducted at Poly house, Research Field, Department of Horticulture, Naini Agricultural Institute (NAI), SHUATS, during rabi season, 2019-2020. The experiment was laid out in randomized block design with three replications. Different concentration of Arka microbial consortium (AMC) with 11 treatment combination was tried. The seeds of lettuce (cv. Grand rapid) and Arka microbial consortium (AMC) were collected from IIHR (Indian institute of horticulture research) Bangalore.

The land preparation was done by deep ploughing, leveling and other agronomic practices were done throughout the research. Each parameter was recorded at 15 days interval. The data recorded was examined statistically using ANOVA and compared the means of growth yield and quality parameters of lettuce. Hence this experiment was focused to assess the best treatment combination of Arka microbial consortium under poly house in Prayagraj agro climatic condition.

\section{Results and Discussion}

The application of arka microbial consortium showed remarkable and requisite effect on growth, yield and quality parameters of lettuce (Fig. 1-3 and Table 1-3).

\section{Growth parameters}

Growth, yield and quality of lettuce are influenced by different concentrations of Arka microbial consortium. Among the different concentrations; $10 \mathrm{~g}$ Arka microbial consortium $+75 \%$ recommended dose of 
nitrogen, phosphorous and $100 \%$ potassium gave the minimum days to germination (4.07) followed by (4.43) $8 \mathrm{~g}$ arka microbial consortium $+75 \%$ recommended dose of nitrogen, phosphorous and $100 \%$ potassium. Maximum days to germination (6.38) were recorded in control treatment. Maximum plant height $(13.74 \mathrm{~cm})$ was recorded in $10 \mathrm{~g}$ arka microbial consortium $+75 \%$ recommended dose of nitrogen, phosphorous and $100 \%$ potassium followed by (12.81) $8 \mathrm{~g}$ Arka microbial consortium $+75 \%$ recommended dose of nitrogen, phosphorous and 100\% potassium and minimum $(8.78 \mathrm{~cm})$ was observed in control. The maximum number of leaves/plant (10.58) was recorded in $10 \mathrm{~g}$ Arka microbial consortium $+75 \%$ recommended dose of nitrogen, phosphorous and $100 \%$ potassium followed by (9.86) $8 \mathrm{~g}$ Arka microbial consortium $+75 \%$ recommended dose of nitrogen, phosphorous and $100 \%$ potassium and minimum (7.18) was observed in control. These results can be concluded to a reason that the production of plant growth promoting substances by plant growth promoting bacteria significantly increased the cell division, higher nitrogen fixation, phosphorus and zinc solubilization; resulting in early germination, higher number of leaves and maximum plant height and etc. The present study was also supported by the findings of Shenoy and Kalagudy (2012) and Jayashree et al., (2016).

\section{Yield parameters}

Minimum days to first harvest (29.63), last harvest (38.45), and minimum harvesting duration (5.57) was recorded in $10 \mathrm{~g}$ Arka microbial consortium $+75 \%$ recommended dose of nitrogen, phosphorous and $100 \%$ potassium and maximum days to first harvest (36.52), last harvest (45.52), and maximum harvesting duration (8.25) was recorded in control. The yield parameters; average weight of the plant $(164.30 \mathrm{~g})$ and average weight of trimmed head (133.54g) was recorded in $10 \mathrm{~g}$ Arka microbial consortium $+75 \%$ recommended dose of nitrogen, phosphorous and $100 \%$ potassium and minimum average weight of the plant (g) (110.38) and average weight of trimmed head (81.20) was found in control. The maximum yield $/$ plot $(4.80 \mathrm{~kg})$ and yield/ha (10.88t) was recorded in $10 \mathrm{~g}$ Arka microbial consortium $+75 \%$ recommended dose of nitrogen, phosphorous and $100 \%$ potassium and minimum yield/plot (kg) (2.91) and yield/ha(ton) (6.59) was found in control.

\section{Quality parameters and organoleptic test}

In quality parameters- Total soluble solids (5.41 ${ }^{\circ}$ Brix) and Vitamin C (8.66 mg/100g), and the overall acceptability in organoleptic test was also recorded maximum in $10 \mathrm{~g}$ Arka microbial consortium $+75 \%$ recommended dose of nitrogen, phosphorous and $100 \%$ potassium. The least values were recorded in control under poly house in Prayagraj agro climatic condition. The increase in Vitamin $\mathrm{C}$ content might be due to the growth promoting substances produced by microbes in AMC, which could have accelerated synthesis of carbohydrates, resulting in increase in Vitamin C content which is a sugar acid Kamali et al., (2002).

\section{Economics}

The maximum gross return ((Rs. 380800/ha), net return (Rs. 318295.00/ha) benefit cost ratio (1:6.09) was recorded in $10 \mathrm{~g}$ arka microbial consortium $+75 \%$ recommended dose of nitrogen, phosphorous and 100\% potassium, and the minimum was observed in control treatments, gross return ((Rs. 230650/ha), net return (Rs. 176050.00/ha) benefit cost ratio (1:4.22). 
Table.1 Evaluation of different concentration of AMC on growth parameters

\begin{tabular}{|c|c|c|c|c|c|c|}
\hline $\begin{array}{c}\text { Treatment } \\
\mathbf{S}\end{array}$ & $\begin{array}{c}\text { Days to } \\
\text { germination }\end{array}$ & $\begin{array}{c}\text { Plant height } \\
(\mathbf{c m})\end{array}$ & $\begin{array}{c}\text { No of } \\
\text { leaves/plant }\end{array}$ & $\begin{array}{c}\text { Days to First } \\
\text { harvest }\end{array}$ & $\begin{array}{c}\text { Days to last } \\
\text { harvest }\end{array}$ & $\begin{array}{c}\text { Harvesting } \\
\text { duration }\end{array}$ \\
\hline $\mathrm{T}_{0}$ & 6.38 & 8.78 & 7.18 & 36.52 & 45.52 & 8.25 \\
\hline $\mathrm{T}_{1}$ & 5.33 & 10.69 & 8.11 & 32.41 & 44.55 & 7.17 \\
\hline $\mathrm{T}_{2}$ & 5.63 & 11.39 & 8.04 & 34.52 & 43.63 & 6.45 \\
\hline $\mathrm{T}_{3}$ & 4.87 & 10.89 & 8.46 & 33.15 & 39.46 & 6.27 \\
\hline $\mathrm{T}_{4}$ & 4.90 & 11.77 & 9.02 & 34.52 & 39.52 & 6.13 \\
\hline $\mathrm{T}_{5}$ & 4.69 & 10.5 & 8.55 & 35.41 & 41.63 & 6.08 \\
\hline $\mathrm{T}_{6}$ & 4.77 & 12.42 & 9.43 & 32.45 & 39.45 & 5.75 \\
\hline $\mathrm{T}_{7}$ & 5.01 & 11.32 & 8.0 & 35.33 & 42.52 & 6.01 \\
\hline $\mathrm{T}_{8}$ & 4.43 & 12.81 & 9.86 & 31.45 & 40.15 & 5.70 \\
\hline $\mathrm{T}_{9}$ & 4.95 & 10.81 & 7.57 & 34.44 & 41.66 & 5.87 \\
\hline $\mathrm{T}_{10}$ & 4.07 & 13.74 & 10.58 & 29.63 & 38.45 & 5.57 \\
\hline $\mathbf{C D}(\mathbf{0 . 0 5})$ & $\mathbf{0 . 9 5 1}$ & $\mathbf{1 . 1 4 4}$ & $\mathbf{0 . 7 0 3}$ & $\mathbf{2 . 3 5 7}$ & $\mathbf{2 . 4 0 2}$ & $\mathbf{0 . 4 7 0}$ \\
\hline
\end{tabular}

Table.2 Evaluation of different concentration of AMC on yield parameters

\begin{tabular}{|c|c|c|c|c|}
\hline Treatments & $\begin{array}{l}\text { Average weight } \\
\text { of plant (g) }\end{array}$ & $\begin{array}{l}\text { Average weight } \\
\text { (Trimmed head) } \\
\text { (g) }\end{array}$ & $\begin{array}{l}\text { Yield per } \\
\text { plot (kg) }\end{array}$ & $\begin{array}{l}\text { Yield/ha } \\
\text { (ton) }\end{array}$ \\
\hline $\mathrm{T}_{0}$ & 110.38 & 81.20 & 2.91 & 6.59 \\
\hline $\mathrm{T}_{1}$ & 114.76 & 84.81 & 3.04 & 6.88 \\
\hline $\mathrm{T}_{2}$ & 115.53 & 88.62 & 3.18 & 7.20 \\
\hline $\mathrm{T}_{3}$ & 127.96 & 104.88 & 3.46 & 8.54 \\
\hline $\mathrm{T}_{4}$ & 121.34 & 93.41 & 3.35 & 7.59 \\
\hline $\mathrm{T}_{5}$ & 127.03 & 96.31 & 3.60 & 8.16 \\
\hline $\mathrm{T}_{6}$ & 136.22 & 105.13 & 3.77 & 8.56 \\
\hline $\mathrm{T}_{7}$ & 131.38 & 100.23 & 3.78 & 7.84 \\
\hline $\mathrm{T}_{8}$ & 141.89 & 113.67 & 4.08 & 9.24 \\
\hline $\mathrm{T}_{9}$ & 121.01 & 94.44 & 3.39 & 7.68 \\
\hline $\mathrm{T}_{10}$ & 164.30 & 133.54 & 4.80 & 10.88 \\
\hline $\mathbf{C D}(\mathbf{0 . 0 5})$ & $\mathbf{4 . 1 2 7}$ & $\mathbf{3 . 4 8 8}$ & $\mathbf{0 . 1 3 2}$ & $\mathbf{0 . 2 9 5}$ \\
\hline
\end{tabular}


Table.3 Evaluation of different concentration of AMC on quality parameters and Organoleptic test

\begin{tabular}{|c|c|c|c|}
\hline Treatments & $\begin{array}{c}\text { Total soluble solids } \\
\text { (Brix) }\end{array}$ & $\begin{array}{c}\text { Vitamin C } \\
(\mathbf{m g} / \mathbf{1 0 0 g})\end{array}$ & $\begin{array}{c}\text { Overall } \\
\text { acceptability }\end{array}$ \\
\hline $\mathrm{T}_{0}$ & 4.10 & 6.57 & 5.73 \\
\hline $\mathrm{T}_{1}$ & 4.46 & 7.23 & 6.80 \\
\hline $\mathrm{T}_{2}$ & 4.34 & 7.80 & 6.60 \\
\hline $\mathrm{T}_{3}$ & 4.33 & 7.63 & 7.33 \\
\hline $\mathrm{T}_{4}$ & 4.57 & 7.35 & 6.33 \\
\hline $\mathrm{T}_{5}$ & 4.28 & 7.35 & 6.53 \\
\hline $\mathrm{T}_{6}$ & 5.17 & 8.12 & 6.20 \\
\hline $\mathrm{T}_{7}$ & 4.46 & 7.23 & 6.33 \\
\hline $\mathrm{T}_{8}$ & 5.27 & 8.46 & 6.60 \\
\hline $\mathrm{T}_{9}$ & 4.59 & 7.52 & 7.87 \\
\hline $\mathrm{T}_{10}$ & 5.41 & 8.66 & 7.87 \\
\hline $\mathbf{C D}(\mathbf{0 . 0 5})$ & $\mathbf{0 . 6 9 6}$ & $\mathbf{0 . 2 6 4}$ & $\mathbf{0 . 4 8 2}$ \\
\hline
\end{tabular}

Fig.1 Histogram depicting performance of different concentration of AMC on days to germination, plant height, number of leaves per plant

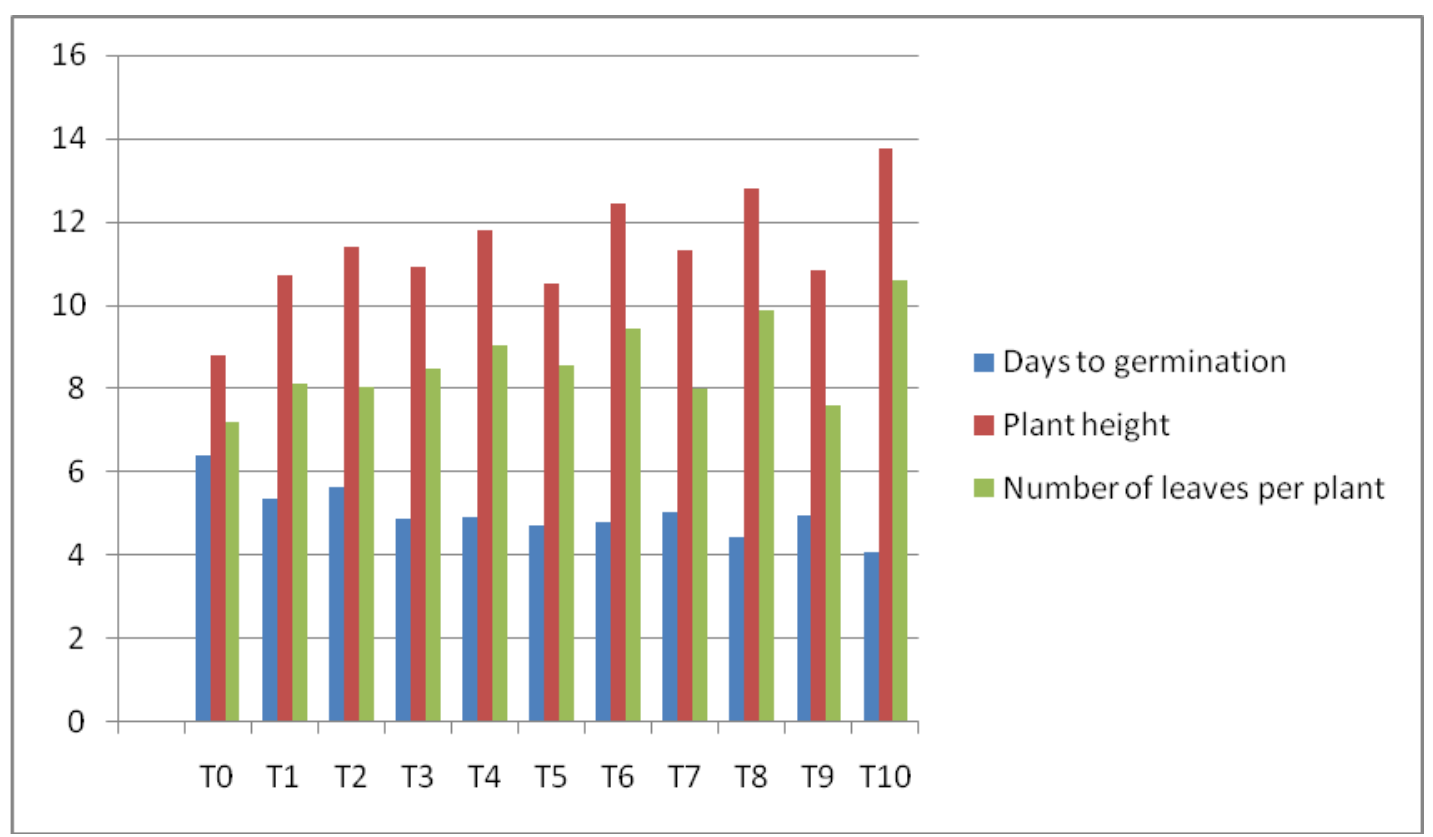


Fig.2 Histogram depicting performance of different concentration of AMC on yield per plot and yield per hectare

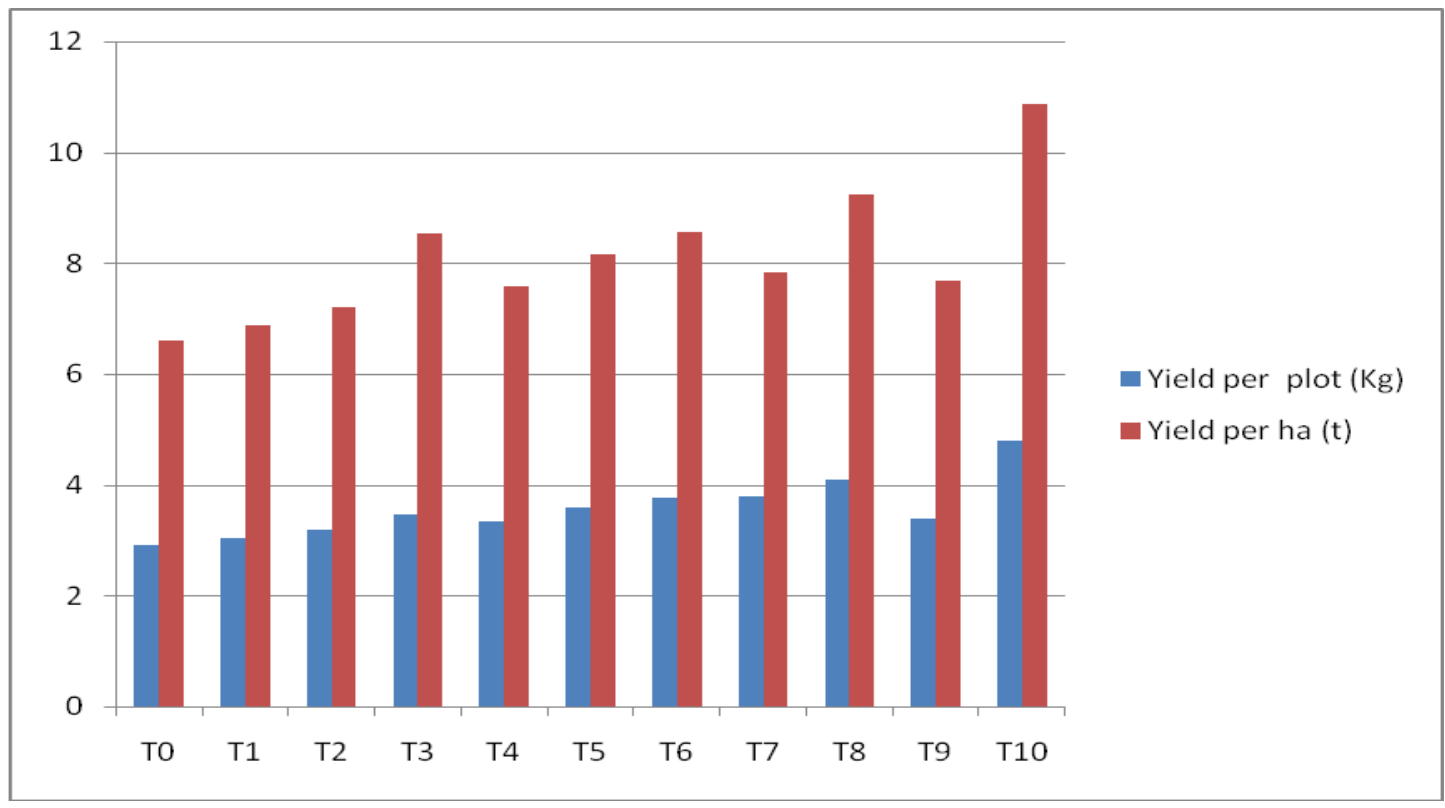

Fig.3 Histogram depicting performance of different concentration of AMC on Quality parameters and Organoleptic test

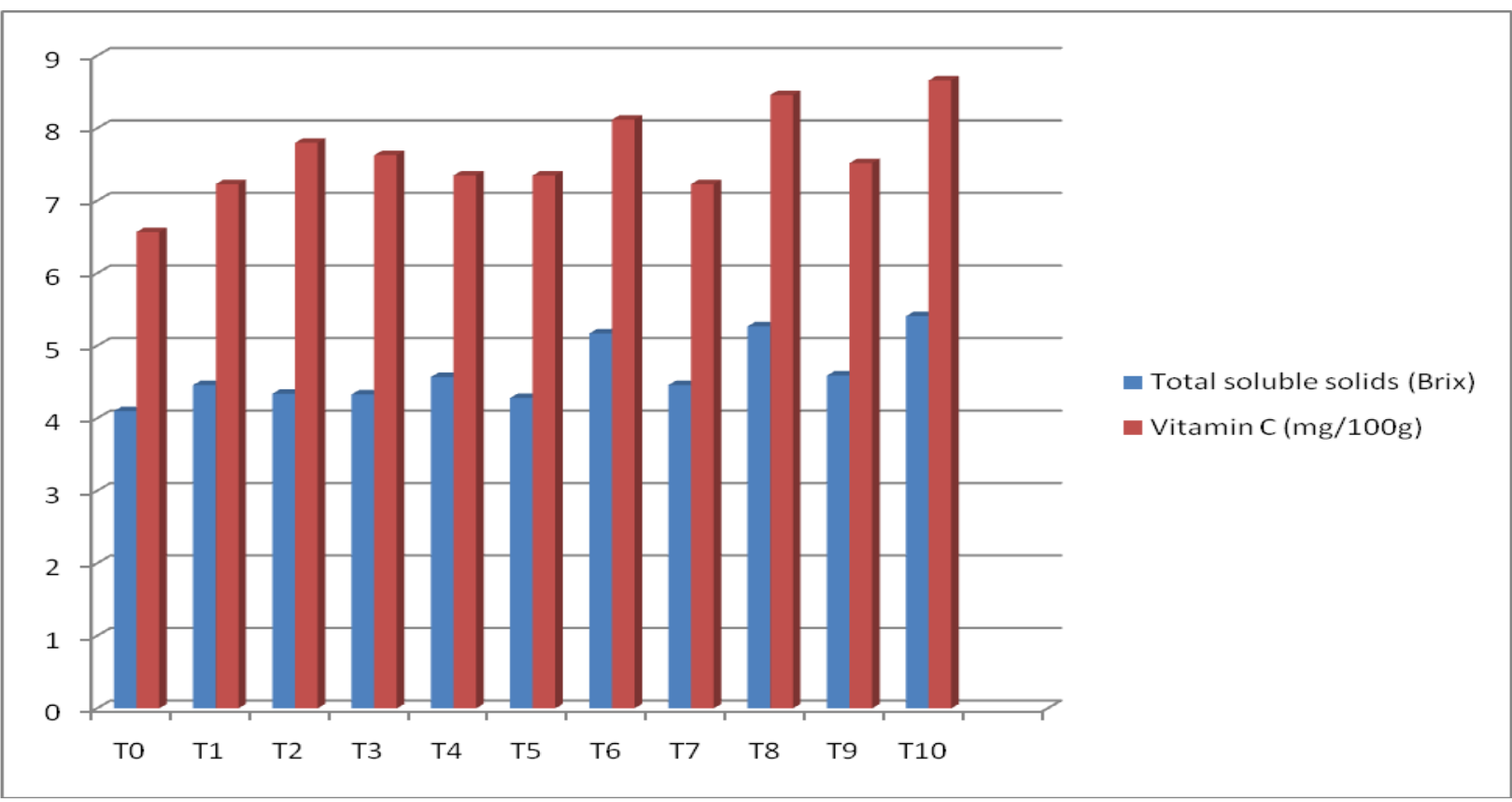

Based on the present investigation it is concluded that Growth yield and quality of lettuce was influenced by different concentration of Arka microbial consortium
$.10 \mathrm{~g}$ AMC Recorded maximum performance with respect to almost all the vegetative growth Yield as well as Quality characteristics. Control treatment, showed 
poor performance out of all the treatments applied. By using AMC harvesting was early as compared normal Harvest,10g AMC also recorded maximum for gross return, net return and for cost benefit ratio. Therefore, treatment $10 \mathrm{~g}$ arka microbial consortium $+75 \%$ recommended dose of nitrogen, phosphorous and $100 \%$ potassium and treatment $8 \mathrm{~g}$ arka microbial consortium $+75 \%$ recommended dose of nitrogen, phosphorous and 100\% potassium could be economically good option for small and marginal farmers for cultivation in Prayagraj

\section{Acknowledgement}

My proud privilege to express a deep sense of gratitude to my advisor Prof. (Dr.) V. M. Prasad, Professor, Department of Horticulture, Naini Agricultural Institute, SHUATS, Prayagraj whose generous help, untiring guidance, supervision, suggestions and positive attitude during my work. I express a deep sense of gratitude to all the teaching staff members of Department of Horticulture, Dr. S. S. Saravanan, Dr. Devi Singh, Dr. Vijay Bahadur, Dr. Samir E Topno , Mr. Deepanshu , Dr. Urfi Fatmi and Mr. Deepak Lal for their persistent help and valuable information's regarding the work.

\section{References}

Anjani Sahu, K.P. Verma, Amrotin Teta and Lahari Karumuri (2017) Effect of compost derived from decomposed kitchen waste by microbial decomposers on plant growth parameters of crops. Journal of Pharmacognosy and Phytochemistry 2017, 1: 435-438

Chatto, M A., Gandorio M Y and Zargar M Y. 1997. Effect of Azospirillum and Azotobacter on growth and quality of knolkhol (Brassica oleracea L. Var. gongylodes). Vegetable Science, 24: 16-
19

Jayashree, C. and Jagadeesh, K.S. 2016, Nursery inoculation of the selected vegetable seedlings with a microbial consortium and its field performance in brinjal (Solanum melongena L.). M.Sc Thesis, Univ. Agric. Sci., Dharwad

Kamal Kant, Devi Singh and V. M. Prasad (2019). Effect of Microbes and Fertilizers on Growth and Yield of Cabbage (Brassica oleracea L. var. capitata). International Journal of Current Microbiology and Applied Sciences (2019), 8(12): 2204-2212

Mahato P., Badoni. A. Chauhan J. S. (2009) Effect of azotobacter and nitrogen and seed germination and early seedling growth in Tomato. Research 1(4): 62-62

Menka Pathak, Dr. Pradyumna Tripathy, Dr. SK Dash, Dr. GS Sahu and Dr. SK Pattanayak (2017). Effect of source of nutrient on growth, yield and quality of Radish (Raphanus sativus L.) in radish coriander cropping sequence. The Pharma Innovation Journal 2017,6 (12): 496-499

Mohammadullah Nikzad, Aravinda J. S. Kumar, Anjanappa M., Amarananjundeswara H., Dhananjaya B. N. and Basavaraj G. (2019). Effect of Fertigation, Levels on Growth and Yield of Cabbage (Brassica oleracea L. var. capitata). International Journal of Current Microbiology and Applied Sciences (2020), 9(1): 1240-1247

Sarvanan, T.S., Rajendran, K. and Santhaguru, K. 2012. Selection of suitable bio-fertilizer for production of quality seedling of Casurina equisetifolia using decomposed coir pith compost in Root Trainers. Asian J. Exptl. Biol. Sci., 3(4): 752-761

Spacing M. R. Hasan, A.K.M.M. Tahsin, M. N. Islam, M. A. Ali and J. Uddain (2017) Growth and Yield of Lettuce (Lactuca sativa L.) Influenced As 
Nitrogen Fertilizer and Plant IOSR Journal of Agriculture and Veterinary Science (IOSR-JAVS). PP 62-71

Stefanelli, D., Brady, S., Winkler, S., Jones , R.B. and Tomkins, B.T. (2012). Lettuce (Lactuca sativa 1.) growth and quality response to applied nitrogen under hydroponic conditions Acta Horticulturae, 927, 353-359. Venkkedasubhaja, K., R.V.S.K. Reddy, G. shaluraju, E. Karunasree, V. Shekhar, T. Vijayanirmala, A. Devivaraprasad Reddy and V. Deepthi. (2018). Effect of different level of Arka microbial consortium on seed germination and survival rate in Brinjalcv. Dommerulocal. Agriculture Information centre.IIHR Bengaluru.

\section{How to cite this article:}

Aswathi, N. C., V. M. Prasad and Gadha Sreekumar. 2020. Effect of Different Concentration of Arka Microbial Consortium on the Growth Yield and Quality of Lettuce (Lactuca sativa) $c v$. Grand rapid under Poly House in Prayagraj Agro Climatic Condition. Int.J.Curr.Microbiol.App.Sci. 9(12): 1135-1143. doi: https://doi.org/10.20546/ijcmas.2020.912.137 